0

\title{
Experimental analysis of solar thermal integrated MD system for cogeneration of drinking water and hot water for single family villa in Dubai using flat plate and evacuated tube solar collectors
}

\author{
Muhammad Asim, ${ }^{\mathrm{a}, \mathrm{w}}$, Muhammad Imran ${ }^{\mathrm{b}, \mathrm{c}}$, Michael K.H. Leung ${ }^{\mathrm{a}}$, N.T. Uday Kumar ${ }^{\mathrm{d}}$, \\ Andrew R. Martine, Faiza Kashif ${ }^{\mathrm{f}}$ \\ "Ability RED Energy Research Centre (AERC), School of Energy and Environment, City University of Hong Kong, Hong Kong, \\ Tel.+852 5909 3787; email: muhamasim2-c@my.cityu.edu.hk (M. Asim) \\ ${ }^{b}$ Department of Energy Engineering, School of Engineering, University of Management and Technology, C-II Johar Town, \\ Lahore 54700, Pakistan, Tel.+92 345 5573234; email: muhammadimran@umt.edu.pk \\ 'Department of Mechanical Engineering, Technical University of Denmark, Building 403, 2800 Kongens Lyngby, Denmark, \\ Tel.+45 71323659; email: mimran@mek.dtu.dk \\ ${ }^{d} R A K$ Research and Innovation Center, American University of Ras Al Khaimah (AURAK), Ras Al Khaimah, \\ United Arab Emirates (UAE), Tel.+971 501954502; email: uday.kumar@aurak.ac.ae \\ ${ }^{e}$ Department of Energy Technology, KTH Royal Institute of Technology, 10044 Stockholm, Sweden, Tel. +46 87907473; \\ email: andrew.martin@energy.kth.se \\ ${ }^{f}$ Department of Structures E Environmental Engineering, University of Agriculture Faisalabad, Tel. +923314858833 ; \\ email: faizakashif054@gmail.com
}

Received 16 May 2017; Accepted 27 September 2017

\section{A B S T R A C T}

This paper presents the experimental analysis performed on solar thermal integrated membrane distillation (MD) system using flat plate and evacuated tube collectors. The system will be utilized for cogeneration of drinking water and domestic hot water for single family in Dubai comprising of four to five members. Experiments have been performed in Ras Al Khaimah Research and Innovation Centre (RAKRIC) facility. The experimental setup has been installed to achieve the required production of $15-25 \mathrm{~L} / \mathrm{d}$ of drinking water and $250 \mathrm{~L} / \mathrm{d}$ of hot water for domestic purposes. Experiments have been performed on MD setup at optimized flow rates of $6 \mathrm{~L} / \mathrm{min}$ on hot side and $3 \mathrm{~L} / \mathrm{min}$ on cold side for producing the desired distillate. The hot side and cold side MD temperature has been maintained between $60^{\circ} \mathrm{C}$ and $70^{\circ} \mathrm{C}$, and $20^{\circ} \mathrm{C}$ and $30^{\circ} \mathrm{C}$. The total annual energy demand comes out to be $8,223 \mathrm{kWh}(6,000 \mathrm{kWh}$ is for pure water and $2,223 \mathrm{kWh}$ for hot water). The optimum aperture areas for flat plate and evacuated tube collector field have been identified as 8.5 and $7.5 \mathrm{~m}^{2}$, respectively. Annual energy consumption per liter for pure water production is $1,0.85$ and $0.7 \mathrm{kWh} / \mathrm{L}$ for different $\mathrm{MD}$ hot and cold inlet temperatures.

Keywords: Membrane distillation; RAKRIC; Flat plate collectors; Evacuated tube collectors; Annual energy demand

\section{Introduction}

The unavailability of potable water resources in Arab countries, specifically in UAE, has affected many lives and

${ }^{*}$ Corresponding author. livelihood of inhabitants living there. In arid regions, water is very precious commodity. The issue of water shortage in these countries is likely to approach the crisis level because the groundwater resources are nonrenewable and surface water resources are unavailable [1]. The drastic shortfall of rain and unavailability of the sufficient water resources are deteriorating the water quality in UAE [2] 
$\mathrm{UAE}$ is one of the most rapidly growing countries in Middle East and North African (MENA) region showing the abrupt increase in population in past few decades. In 2013, the average consumption of bottled water per resident is $141 \mathrm{~L}$ as compared with the global average of $37.5 \mathrm{~L}$ per person. According to the survey of Euromonitor International, more than 1 billion L of bottled water is sold every year in UAE generating total revenue of about 1.4 billion dirhams. By this growth rate, the bottled water will generate revenue of about 2 billion dirhams by the end of 2019 [3].

With a low average precipitation rate in UAE (78 mm/year) as compared with United States (715 mm/year) and Korea (1,274 mm/year) [5], the bottled water consumption is increasing creating a lot of stress on underground aquifers. UAE is amongst the top 10 countries having highest per capita domestic water consumption (550 L/d per person) which is twice the global average (250 L/d per person) [4]. The water demand in UAE rises exponentially every year because of the high temperature, increase in domestic water consumption, rapid population, industrial growth and low rainfall. The low precipitation rates, scarce rainfall and limited water resources of UAE are some of the major problems that can only be solved by discovering new water resources.

According to a study conducted by Italian Trade Commission, the domestic household water consumption in UAE is about $24 \%$ and only $9 \%$ is utilized by the industrial sector whereas the agriculture sector consumes about $67 \%$ [5]. In future, the per capita availability of the water will be reduced to half and serious shortfall of the water will occur.

Therefore, in order to fulfill the demand of drinking water and domestic hot water, seawater desalination is considered the most suitable strategy. According to International Desalination Association (as of 30th June 2015), the total number of desalination plants that has been installed worldwide over 150 countries counts 18,426 with a total global desalination capacity of 86.8 million cubic meters of water per day. More than 300 million people around the world depend on desalinated water to fulfill their daily needs [6]. UAE is the world's second largest producer of desalinated water after Saudi Arabia, which pumps nearly 2.02 billion cubic meters of desalinated water per year [7].

In UAE, people mostly use the bottled water for drinking purpose which is supplied to the end users in the form of 5 gal containers. The yearly consumption of bottled water in UAE is about 1.2 billion L out of which $60 \%$ are "home office delivery" in bulk supplies [8]. The bottled water consumption has been increasing day by day resulting in increasing demand for drinking water. Considering the above statistics regarding drinking water trends in $\mathrm{UAE}$, a sustainable way needs to be adopted in order to fulfill the demand of pure drinking water and domestic hot water.

A lot of thermal and physical desalination technologies are well established commercially in order to desalinate water for its use in domestic as well as for industrial applications. Membrane distillation (MD) is a promising desalination technology which can be used for desalination as well as for recycling. MD processes can be classified into four basic configurations on the basis of the methods to induce vapor pressure gradient and to collect the transported vapors. Direct contact membrane distillation has been the most studied model due to its inherent simplicity [9]. On the other hand, vacuum membrane distillation can be used for high output while air gap membrane distillation (AGMD) and sweep gas membrane distillation enjoy the benefit of low energy losses and high performance ratio [10-12]. MD technique involves the removal of water vapors from warm aqueous feed solution at a temperature below $100^{\circ} \mathrm{C}$ and has been proposed as an alternative for producing portable pure drinking water [20].

Meindersma et al. [13] carried out an industrial research on solar driven MD system to produce pure water through AGMD to produce the pure drinking water at cost of about $\$ 0.50 / \mathrm{m}^{3}$, even as low as $\$ 0.26 / \mathrm{m}^{3}$ depending on the thermal heat source. Chafidz et al. [14] developed portable hybrid solar powered MD system for production of fresh water using vacuum multi-effect MD. The total volume distillate output during the test was approximately $70 \mathrm{~L}$ with an approximate conductivity of $4.7 \mu \mathrm{S} / \mathrm{cm}$. The average distillate output rate was $11.53 \mathrm{~L} / \mathrm{h}$ with the maximum of $15.94 \mathrm{~L} / \mathrm{h}$ at noon time, whereas the distillate flux was in the range of $1.5-2.6 \mathrm{~L} / \mathrm{m}^{2} \mathrm{~h}$.

Kullab et al. [15] studied the solar thermal integrated AGMD unit having non-concentrating solar thermal collectors. The trials were conducted on this test facility with different parametric analysis (feed stock, total dissolved solid (TDS) levels, temperature and flow rates) and the data from the experiments and related studies demonstrated that the MD unit performance remains insensitive to variations in feedstock qualities (e.g., pH and TDS levels). Banat and Simandl [16] used membranes of different porosities for desalinating water by using AGMD technique. The results demonstrated that the permeate flux increased exponentially with the increase in hot side temperature. The mass flux was steady over time and was affected slightly by increase in salt concentration. Kullab [17] performed the numerical and experimental assessment for water desalination using AGMD technique. In this research study, the three-stage AGMD system performance has been evaluated with saline water $(35 \mathrm{~g} / \mathrm{L}$ of $\mathrm{NaCl})$. The assessing parameters were water quality and energy consumption. The specific thermal energy consumption came out to be $950 \mathrm{kWh} / \mathrm{m}^{3}$ for a layout with no heat recovery whereas for a layout model with heat recovery, the specific thermal energy consumption was $850 \mathrm{kWh} / \mathrm{m}^{3}$.

Qtaishat and Banat [18] tested several small and lab scale plants for MD desalination using solar energy (photovoltaic panels and solar collectors) and is deemed suitable to operate in small capacities. Even though the main cost is the investment cost, once it is installed and become operational, the system becomes relatively inexpensive. Alkhudhiri et al. [19] used AGMD technique to produce drinking water and analyzed the impact of different operating parameters on the performance of three different membranes (TF200, TF450 and TF1000), with different pore sizes of $0.2,0.45$ and $1 \mu \mathrm{m}$, respectively. He analyzed that with increase in feed temperature, the energy consumption and permeate flux of the membranes increases whereas the coolant temperature decreases.

In view of all the above reasons, a pilot plant setup has been commissioned and installed in UAE capable to fulfill the need of drinking water and domestic hot water for a single family in Dubai comprising of four to five members. The main concern of this study is to perform the experimental analysis and calculating the optimum collector area for solar thermal integrated MD setup where the thermal energy has been provided by two types of solar collector fields, that is, flat plate collectors and evacuated tube collectors. 
The experimental analysis has been performed on different solar collector aperture areas to determine the optimized collector area that is required to produce $15-25 \mathrm{~L} / \mathrm{d}$ of pure drinking water and $250 \mathrm{~L} / \mathrm{d}$ of domestic hot water under local conditions of UAE.

\section{Membrane distillation}

MD is a unique separation process based on the transportation of vapors across micro-porous hydrophobic membrane ensuring high quality of pure water. This process is driven by the difference in partial pressure across the membrane. This process has been used extensively in research for various applications such as seawater desalination, waste water treatment, etc. [20]. In AGMD, the partial pressure difference between the hot and cold side serves as a driving force which allows the molecular water vapors to pass through the micro-porous hydrophobic membrane. The suitable hot side operating temperature in AGMD is below $90^{\circ} \mathrm{C}$ and this process is also very beneficial for recovering the heat from cold side. Even though the water recovery ratio is low for MD, it can operate continuously in batch mode.

Duong et al. [21] optimized the single pass pilot AGMD plant for sea water desalination with respect to distillate production as well as thermal and electrical energy consumption. Pilot setup delivered a better performance (i.e., higher distillate production rate and lower specific thermal and electrical energy consumption) when operating at elevated evaporator inlet temperature. Lawal and Khalifa [22] studied the performance of double-stage AGMD unit at various AGMD operating parameters. From experiments, it was observed that the double-stage AGMD is capable of producing a maximum of $128 \mathrm{~kg} / \mathrm{m}^{2} \mathrm{~h}$ of distillate production. The system uses the common cooling chamber to provide the sufficient cooling for two feed chambers [22].

This research study is based on small scale MD system which has some advantages over other conventional water purification techniques such as reverse osmosis. The MD process is capable to operate below atmospheric pressure ( $>1$ bar). The main application areas for AGMD involve desalination, water treatment, food industry and chemical industry. Fig. 1 shows the basic idea behind the concept of AGMD.

The AGMD cassette that is used in the study is shown in Fig. 2. It has a plate and frame configuration with the following specifications:

- Cassette material is hydrophobic polytetrafluoroethylene (PTFE) membrane

- Pore size is $0.2 \mu \mathrm{m}$ having $280 \mu \mathrm{m}$ thickness

- $80 \%$ porosity having membrane area of $0.2 \mathrm{~m}^{2}$.

The AGMD module shown in Fig. 3 contains two aluminum condensing plates with $2.4 \mathrm{~cm}$ gap between them. Cooling channels, in serpentine shapes, are present behind the condensing plates, and are covered with rigid aluminum end plates. The two membranes each having the surface area of $0.1 \mathrm{~m}^{2}$ are thermally welded with the PTFE frame. The hot water enters from the bottom of the cassette and flows out from the top of the cassette after exchanging heat with the cold water that is entering into the cassette. An air gap of $5 \mathrm{~mm}$ is maintained on both side of the cassette. The air gap is reduced to about $1 \mathrm{~mm}$ when the cassette gets filled with water due to bulging of the membrane outwards.

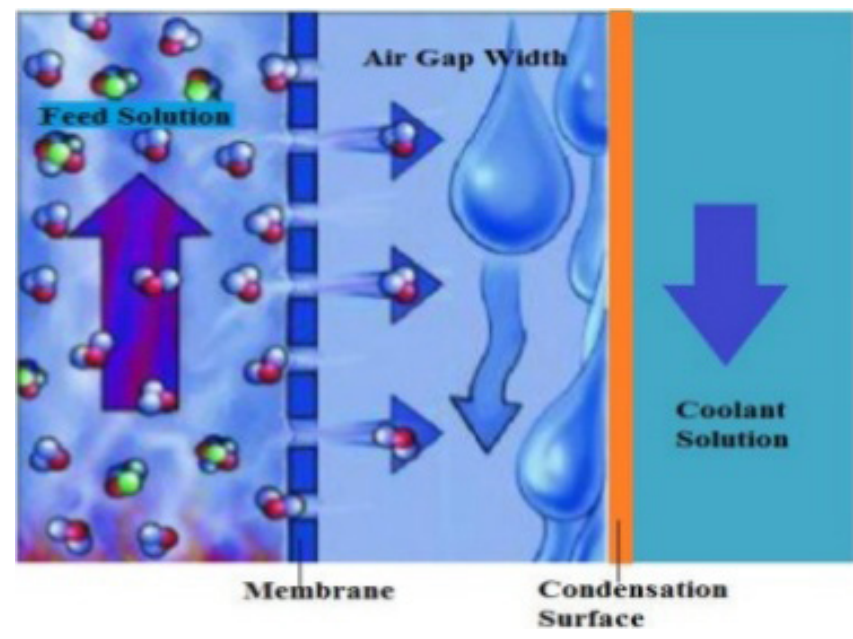

Fig. 1. Air gap membrane distillation technique [23].

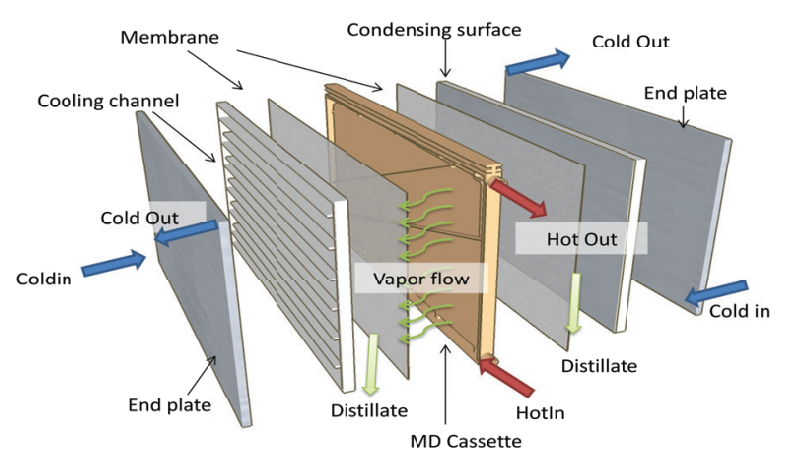

Fig. 2. Laboratory sketch of membrane distillation (MD) module [24].

The principle and laboratory sketch of AGMD shown in Fig. 3 are summarized in three different channels as:

- Hot channel: Hot water enters into the cassette, makes contact with the membrane forming vapors which passes through the membrane.

- Air gap: An air gap is maintained between the outer surface of the membrane and condensation plates which allows the vapors to condense resulting in distillate collection at the bottom.

- Cold channel: The cold water flows from the other side of the condensation plate which absorbs the latent heat of vaporization of water.

Side view of the MD cassette and membrane are shown in Figs. 3(a) and (b).

\section{Methodology and research approach}

For carrying out the research study and to perform the experimental analysis, a solar thermal integrated MD system prototype setup has been designed and installed in UAE. This system is capable of producing pure drinking water and domestic hot water simultaneously in dry UAE region for a single family of four to five persons. The benchmark figures have been set as 15-25 L/d of pure drinking water 

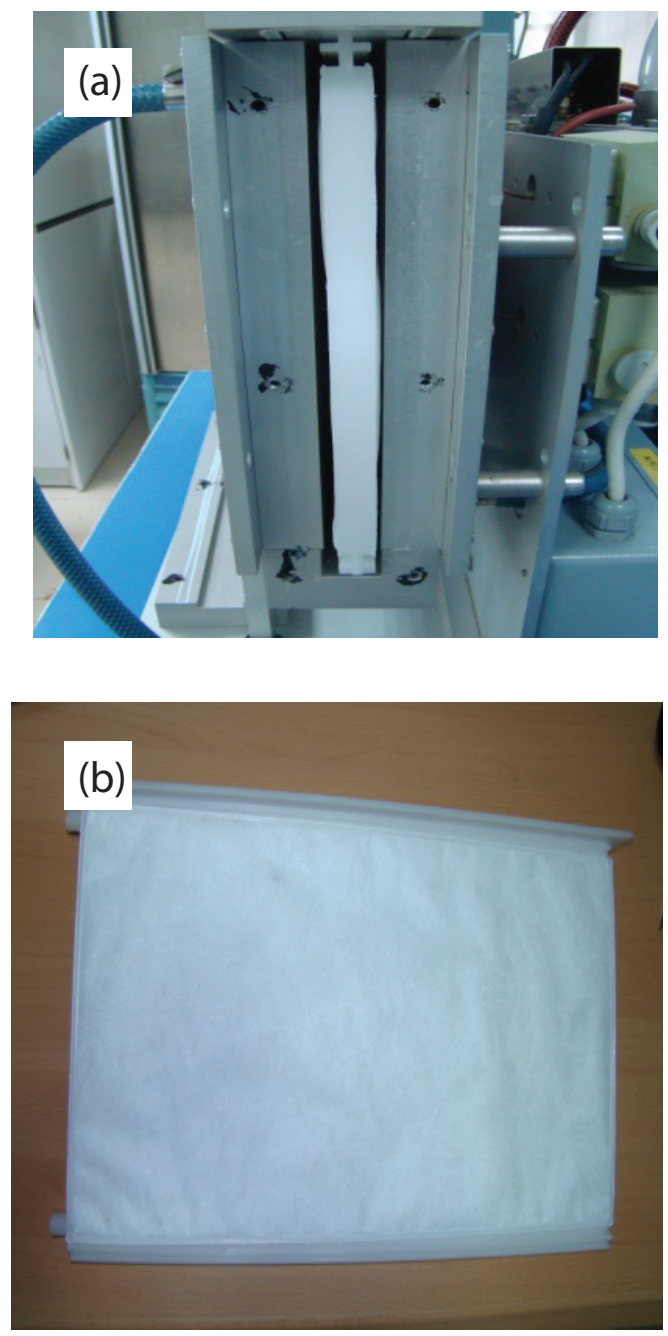

Fig. 3. (a) Side view of MD cassette [24], and (b) PTFE membrane cassette inside module [24].

and $250 \mathrm{~L} / \mathrm{d}$ of domestic hot water using flat plate and evacuated tube collector arrays of varying aperture areas [25]. The objective is to design, install and perform the experimental analysis on this setup for achieving the required drinking water and domestic hot water for single family villa in UAE. Moreover, integrating the solar thermal system with the MD to purify the municipal water is one of the main objectives of the research study.

Fig. 4 shows the prototype of the solar thermal integrated MD system.

Due to low conduction losses, temperature polarization effects and better internal heat recovery as compared with other MD techniques, the AGMD technique has been used in this research study for experiments. The whole experimental setup has been divided into three main circuits as follows:

- Solar thermal heating circuit

- Solar domestic hot water circuit

- MD circuit

The experimental facility has been designed, installed, commissioned and operational in Ras Al Khaimah Research and Innovation Centre (RAKRIC).

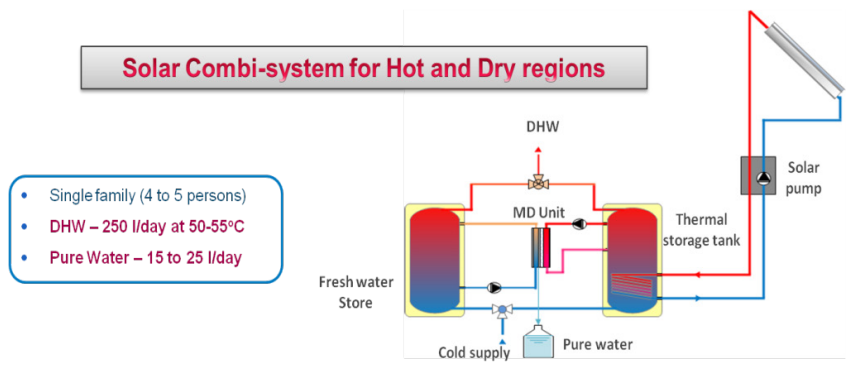

Fig. 4. Solar thermal integrated membrane distillation prototype setup [24].

\section{Solar domestic hot water circuit}

The availability of high solar radiation in MENA region enables us to use solar domestic hot water systems. Typically, the solar domestic hot water systems that have been installed are designed for the $60 \%-70 \%$ annual solar fraction [26]. Back up electric heating is used for the rest of the time to gain energy. In MENA region, the solar fraction throughout the year is high enough to provide heat in order to produce hot water (with $90 \%$ solar fraction) but at such high temperatures and solar fraction, the designers have two main concerns:

- Due to the high stagnation temperature in peak summer times, the system remains idle most of the time and the demand is fulfilled by back up heaters.

- A Legionella bacterium is one of the main concerns in idle systems. The backup heating mechanism kills this bacterium by heating the water up to $60^{\circ} \mathrm{C}$. This makes the solar domestic hot water systems inefficient. Since there is good possibility of operating the system at higher efficiencies [26].

Therefore, the proposed solar thermal integrated MD setup would be an ideal setup in order to enhance the annual solar fraction. This integrated setup also utilizes the extra heat in summers for the production of pure drinking water. In addition to this, mandatory rules and regulations by UAE local authorities encourage to use solar domestic hot water systems from energy conservation point of view.

ESTIDAMA, an urban planning council of Abu Dhabi, is very much interested to encourage people to use solar thermal systems. Therefore, ESTIDAMA has been working with distributors and manufacturers to design the standard sizes of solar thermal systems for variable sizes bedroom villas [27]. So, UAE region could be realized as one of the ideal region to use and implement the concept of solar thermal integrated system keeping in view the conditions, rules and regulations by local authorities.

\section{Experimental setup: integrated MD system}

\subsection{Design of experimental field setup}

The whole experimental setup is based on the combination of three circuits as mentioned in methodology and research approach:

- Solar thermal circuit: This circuit includes solar collector (flat plate and evacuated tube) arrays, complete solar station and thermal storage tank. 
- Domestic hot water circuit: This circuit is comprised of twoway mixing valves, storage tank for collecting domestic hot water and cold water supply tank.

- MD circuit: This circuit contains the single cassette MD module, storage container for distillate flux and storage tank for feed water.

These three circuits constitute the solar thermal integrated MD system with required sensors to monitor the temperature, pressure and flow rate as shown in Fig. 5.

Since the evacuated tube collector field has already been installed onsite, so only flat plate collector design of various aperture areas has been shown in Fig. 5.

\subsubsection{Solar thermal circuit}

As mentioned earlier, solar thermal circuit comprised of the flat plate and evacuated tube solar collectors. Each flat plate collector has an absorber area of $2.55 \mathrm{~m}^{2}$. In total, there are eight flat plate collectors of $20.5 \mathrm{~m}^{2}$ absorber area and they have been arranged into the arrays of different configurations in order to have more operation options for finding out the feasibility of different experiments for cogeneration. As shown in Fig. 5, the first array has an area of $5.1 \mathrm{~m}^{2}$, the second and third arrays have the respective areas of $7.65 \mathrm{~m}^{2}$. Similarly, for evacuated tube collectors, RAKRIC facilities have an evacuated tubular collector field having aperture area of $9.024 \mathrm{~m}^{2}$ (3 collectors, 16 tubes) as shown in Fig. 6(e). In this research study, the experimental results for flat plate collector having aperture area of 11.85 and $7.08 \mathrm{~m}^{2}$ and evacuated tube collector having aperture area of $9.024 \mathrm{~m}^{2}$ have been investigated. In this circuit, the energy transfer mechanism is same for both type of collectors and piping is done in such a manner so that we can operate the flat plate collectors and evacuated tube collectors in variety of arrays combination. The energy from the solar collectors has been transferred to the storage tank to the MD circuit and domestic hot water circuit. To start the solar thermal circuit, the solar collector circuit has been pressurized and solar station pump circulates the water in solar collector arrays and thermal storage tank. The flow rate, temperature and pressure in the solar circuit are continuously monitored and adjusted by the inline flow meters, pressure and temperature sensors. The water flow rate has been adjusted and available solar radiation heats the water inside the collectors. Thermal energy from the collectors is transferred to a stratified thermal storage tank.

\subsubsection{Solar domestic hot water circuit}

Solar domestic hot water system consists of storage tank and control valves. Control valves includes solenoid valve to control quantitative draw off the domestic hot water as

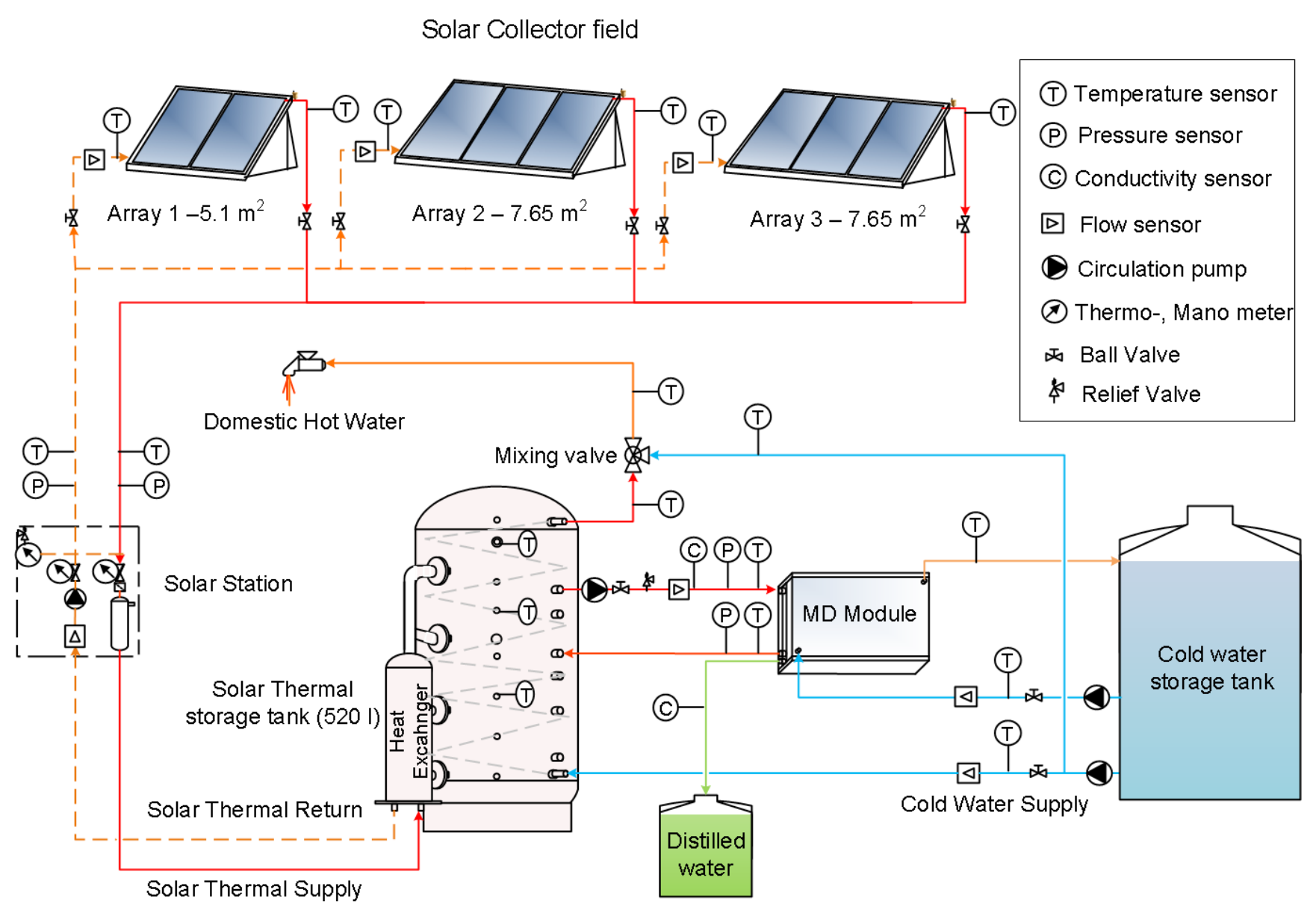

Fig. 5. Solar thermal integrated MD experimental field setup at RAKRIC site [24,28,29]. 


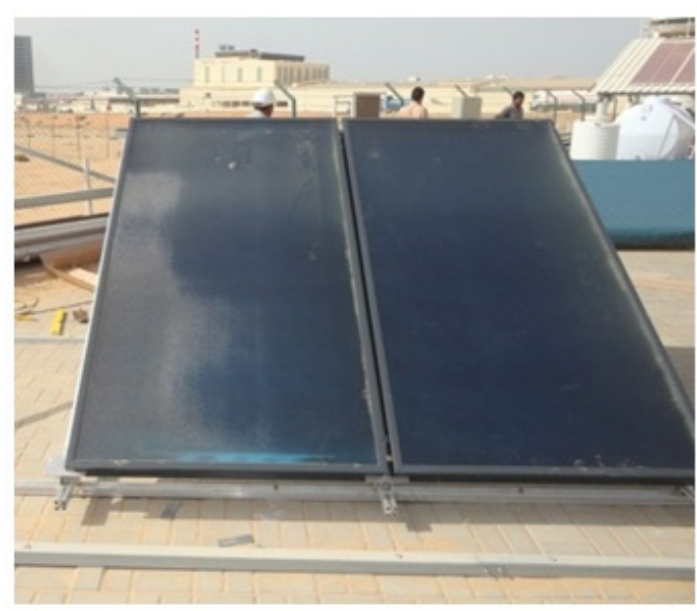

(a)

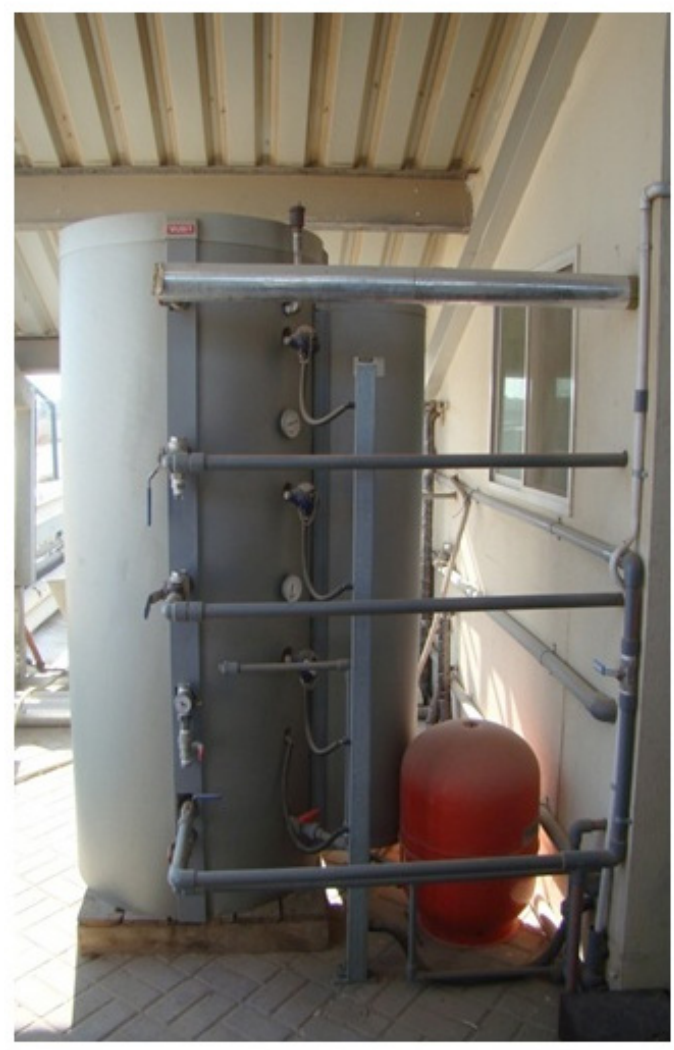

(c)

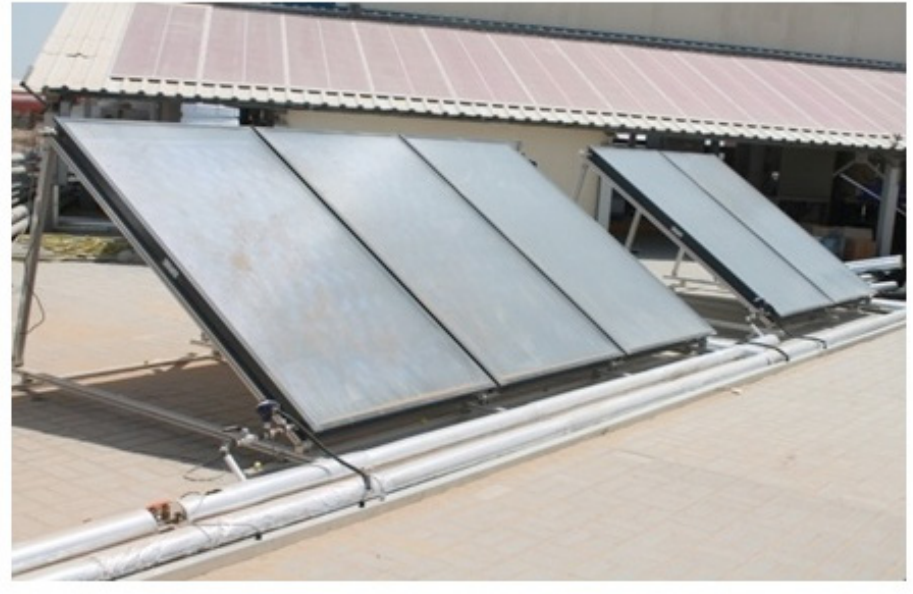

(b)

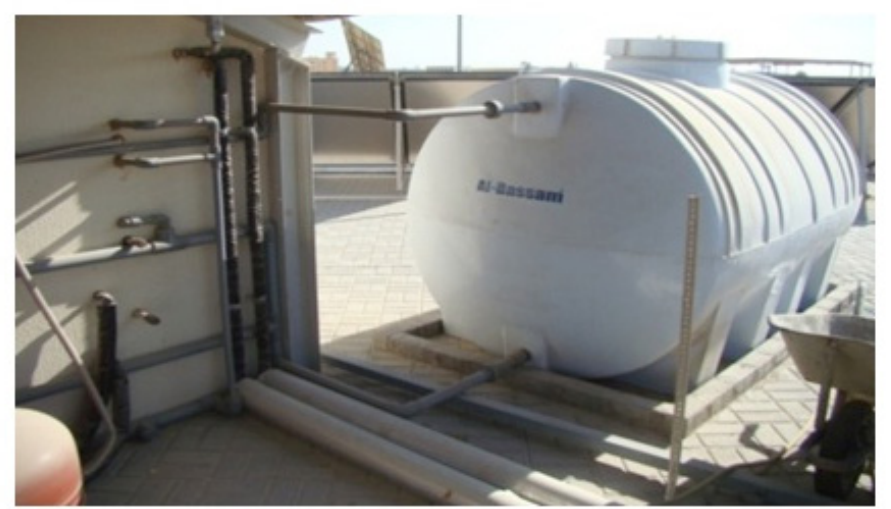

(d)

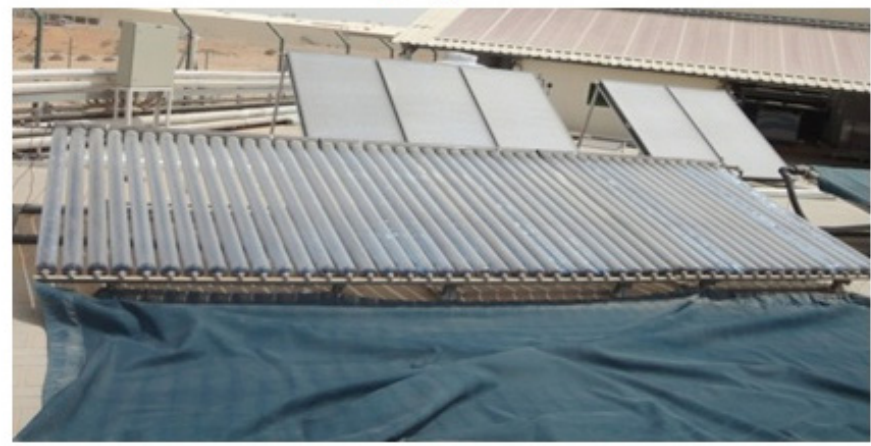

(e)

Fig. 6. (a) Flat plate collector installation, (b) angle adjustment for collectors, (c) stratified thermal storage tank, (d) municipal water storage tank and (e) installed evacuated tube collectors at RAKRIC [24,30].

per requirement of the user and mixing valve for control of desired temperature and mass flow rate of the domestic hot water. Copper pipes insulated with polyisocyanurate have been used to connect the domestic hot water circuit with thermal storage tank. The cold water is drawn off from the cold water storage tank by hydraulic pump. The hot water is drawn off from the hot water storage tank at a flow rate of
$3 \mathrm{~L} / \mathrm{min}$. The cold and hot water are mixed together manually using a three-way valve to get the desired temperature of domestic hot water $\left(45^{\circ} \mathrm{C}-55^{\circ} \mathrm{C}\right)$. The desired temperature is achieved by the manual operation of the mixing valve. Once the desired temperature level has been achieved, the mixing valve position is fixed. The domestic hot water is collected in a separate storage tank. 


\subsubsection{Membrane distillation circuit}

Single cassette MD module has been used in experimental setup. For hot and cold water inflow into the cassette, both hot water storage tank and cold water storage tank have been connected with cassette. Municipal water supply has been used as feed water. The circulation of hot water in the circuit is ensured by the hot water circulation pump. The measurement system consists of pressure sensor, temperature sensor, flow meter, and conductivity sensor and are installed in all major measuring points as shown in Fig. 5. Initially, the different components in MD circuit have been set to specific values for producing the drinking water and domestic hot water as per the energy available from the solar collectors. The experimental results were based on the input conditions fed into the MD system. The results were used as a comparative measure to estimate that their deviation from the standard benchmarks or desired results.

In order to transfer the hot water from storage tank to the MD system, pumps are used. There is also a solar thermal return line from MD to the low temperature zone of the storage tank to conserve energy from water after exchanging heat in MD module. Due to this efficient energy recovery from the return line, the energy demand of MD will be reduced since we are recovering the heat and sending the water back to the thermal storage tank.

\section{Installation and commissioning}

The flat plate collector frames were designed and fabricated as per geometrical details of the solar collectors. The installation of flat plate collector frames is shown in Fig. 6(a). To achieve maximum solar radiation over the year, especially in winter, solar collectors are installed facing south with tilt angle of $35^{\circ}$, as shown in Fig. 6(b). In next step, copper piping is used to connect solar arrays with solar station. To reduce heat loss form copper piping, the whole copper piping network is insulated with polyisocyanurate insulation with insulation thickness of $50 \mathrm{~mm}$ and density of $35-40 \mathrm{~kg} / \mathrm{m}^{3}$. The solar circuit is connected to stratified solar thermal storage tank, as shown in Fig. 6(c). For simultaneous production of hot water and pure drinking water, storage tank is further connected to MD system and solar domestic hot water (SDHW) system. Thermal storage tank is connected with MD system and cold water storage tank via chlorinated polyvinyl chloride piping, as shown in Fig. 6(d). Furthermore, the experimental setup is also integrated with an array of evacuated tubular collectors at RAKRIC facility for comparative analysis during the experimental investigation of MD system, as shown in Fig. 6(e).

Experimental facility with complete MD unit and the solar station circuit is shown Fig. 7.

\section{Experimental analysis}

In next phase, comprehensive experimentation has been performed to investigate the effect of different parameters on distillate production of the integrated pilot plant. Thermal performance of the flat plate and evacuated tube collectors based on their aperture areas has been investigated for feasibility assessment. The optimum area of the flat plate and evacuated tube collectors of integrated pilot plant is estimated for benchmark production. A detailed simulation model has been developed in simulation environment of PolySun. The simulation results of the model are compared with the experimental results. The detail procedure is described as follows.

\subsection{MD operational parameters}

For experimental analysis, detailed experimental approach has been prepared. The operating parameters and their logical bounds of the integrated pilot plant are shown in Table 1.

\subsection{PolySun simulation model}

The PolySun simulation model is shown in Fig. 8. This model is the replica of the experimental setup installed onsite for experimentation purpose. For replicating solar thermal circuit, the inbuilt system components in PolySun has been selected and exact specifications, (as were in experimental setup) such as pipe lengths, flow rates, temperature settings, insulation thickness, etc., have been provided to simulate the system. Solar pump will be switched ON when the temperature difference between the collector outlet and tank lower level is at $6^{\circ} \mathrm{C}$ and switched OFF when the temperature difference is less than $4^{\circ} \mathrm{C}$. Since there is no inbuilt MD system present in the PolySun simulation environment, it is experimentally replicated with energy sink having specific annual demand profile. In the simulated model, the controllers for MD sink and domestic hot water (DHW) have also been used along with the solar station circuit.

\subsubsection{MD energy sink profile}

As mentioned in section 7.2, there is no inbuilt component to model the MD sink in PolySun environment. So a heat sink

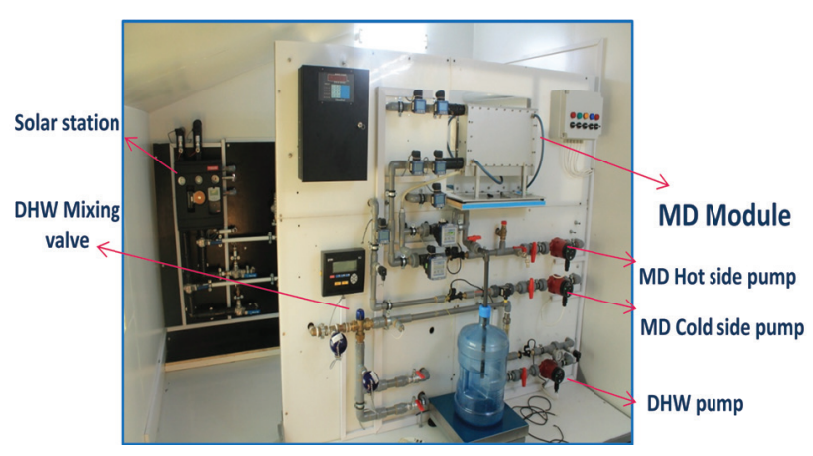

Fig. 7. Solar station and MD circuit $[24,30]$.

Table 1

MD Operation parameters for experimental analysis [24]

\begin{tabular}{ll}
\hline Operational paramentes of MD & Range \\
\hline Concentration of muncipal feed water, ppm & $750-1,000$ \\
Flow rate of muncipal feed water, $\mathrm{L} / \mathrm{min}$ & $4-8$ \\
Flow rate of coolant, $\mathrm{L} / \mathrm{min}$ & $2.5,3,3.5$ \\
MD hot inlet water temperature, ${ }^{\circ} \mathrm{C}$ & $50-75$ \\
MD cold water temperature, ${ }^{\circ} \mathrm{C}$ & $30-40$ \\
\hline
\end{tabular}


component has been used to estimate the energy consumption of MD. A monthly demand profile for the sink has been generated which is based on the minimum temperature levels that could be obtained from the storage tank layer from where the hot water is fed into the MD. With a minimum aperture area of $7 \mathrm{~m}^{2}$, the annual daily simulations for tank layer 9, MD hot in and hot out temperatures are shown in Fig. 9. Using this profile, the average hot in temperature profile has been shown in green color in the same figure.

With the increase in the solar radiation, the tank starts to charge resulting in the increase in the tank top layer temperature. It is obvious that as the tank top layer increases, MD hot in temperature also increases resulting in better heat exchange rate.

\subsubsection{Domestic hot water profile}

For technical viability of the system, it is important to estimate the annual and monthly temperature profiles of the hot and cold water to meet required domestic hot water demand. The standard value of hot water consumption is taken as $50 \mathrm{~L} / \mathrm{d}$ at $50^{\circ} \mathrm{C}$ based on the single person in UAE [25]. This data is further extended to a single family of five members, $250 \mathrm{~L} / \mathrm{d}$, and used in the simulation and experimentation.

For a single family in UAE, daily hot water consumption profile is shown in Fig. 10. The results were obtained from the simulation model developed in PolySun. The constant daily hot water consumption of $250 \mathrm{~L} / \mathrm{d}$ is assumed over the year. However, three peaks of hot water consumption are observed in a single day. As already discussed, the desired temperature of hot water of $50^{\circ} \mathrm{C}$ is controlled via mixing valve shown in Fig. 8.

\subsubsection{Cold water profile}

The annual temperature profile of cold water plays a significant role in the DHW demand. In present study, average tap cold water temperatures are taken as $14^{\circ} \mathrm{C}$ for winter and $30^{\circ} \mathrm{C}$ for summer as per ESTIDAMA recommendation [25]. These recommended temperatures are used in the simulation model in PolySun and the annual profile of monthly averages temperature were obtained, shown in Fig. 11. The simulation results of the annual profile of monthly averages temperature were compared with daily ambient temperature of corresponding month. The simulation results show reasonable agreement with the real-time average monthly ambient temperature. As discussed earlier, heat recovery from cold side of MD effects the overall thermal energy demand. Therefore, it is of crucial importance to analyze the temperature profile of return cold water from MD unit. The lab experimental results indicate that the temperature profile of return cold water from MD unit will increase by $4^{\circ} \mathrm{C}$ in winter and $10^{\circ} \mathrm{C}$ in summer under local conditions of UAE. The temperature profile of return cold water from MD unit is shown in red line in Fig. 11.

\subsection{Comparison of experimental and simulation data}

Keeping in view the abovementioned profiles, the experimental analysis was performed on the setup and real experimentation data inputs have been used to simulate the results.

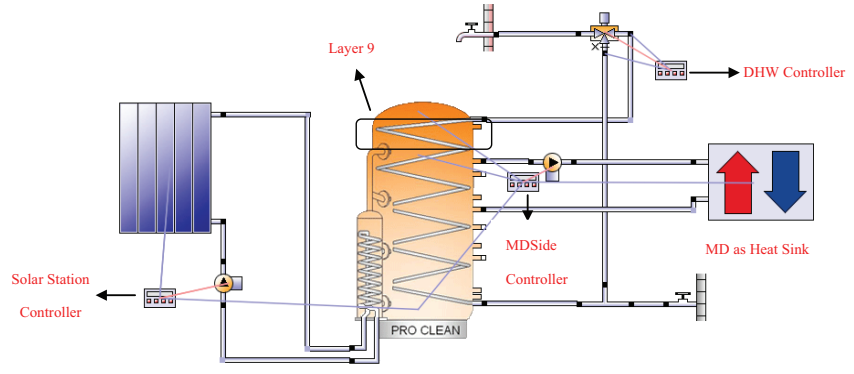

Fig. 8. Schematic diagram of PolySun simulation model [24].

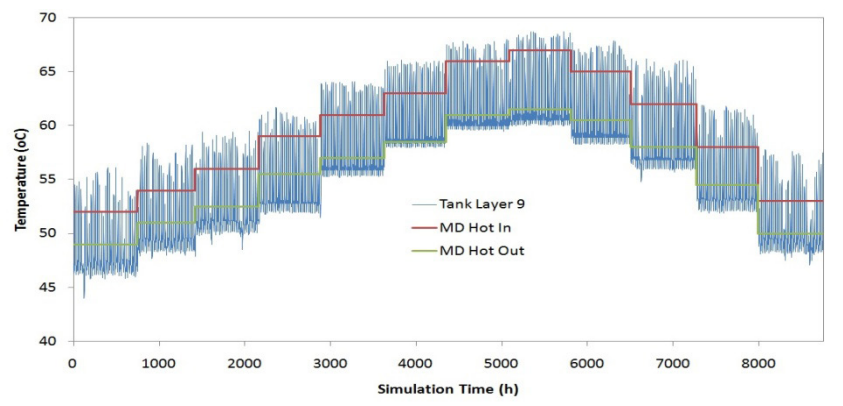

Fig. 9. MD energy sink temperature profile [24].

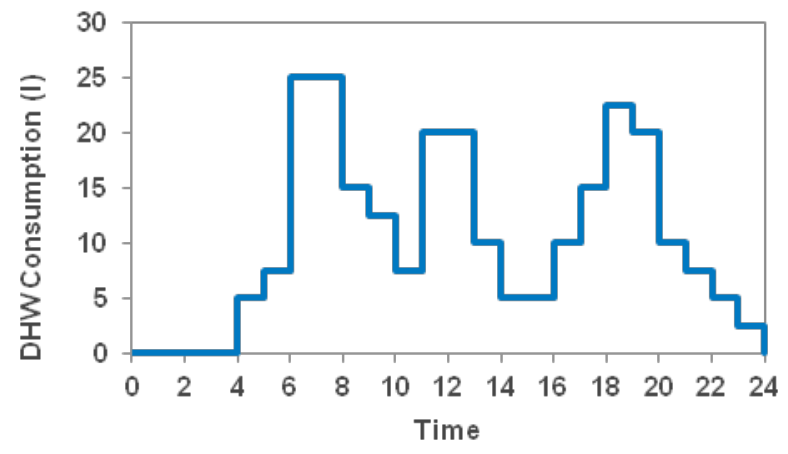

Fig. 10. Daily DHW withdrawal profile [24].

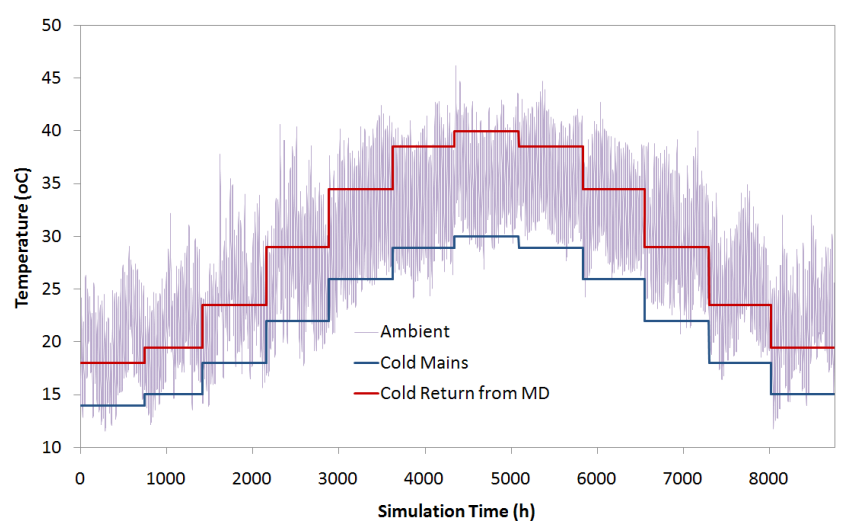

Fig. 11. Cold water temperature profile [24]. 
The experiments have been performed on different days in the month of July. Different configurations of flat plate collectors and evacuated tube collectors with different aperture areas have been employed for experimentation purpose. The simulated and experimental results have been compared to determine real energy demand of MD in comparison with energy sink profile used in simulations. MD hot inlet and outlet temperatures are very crucial and depend on various parameters including solar radiation, collector outlet temperature and thermal storage tank top layer temperature.

\subsubsection{Flat plate collectors}

Aperture area $-11.85 \mathrm{~m}^{2}$ : The flat plate collectors have been arranged in such a way so as to form the two arrays (five collectors). One array has two collectors whereas the other array has three collectors. The total aperture area of the collectors is $11.85 \mathrm{~m}^{2}$. To achieve the high outlet water temperature, the specific flow rate in solar circuit is kept low. The simulations and experimental data for energy consumption estimates on 11th July are provided in Table 2. From the simulations, for $12 \mathrm{~h}$ operation, the total solar yield is $31.3 \mathrm{kWh}$. It is important to notice that MD uses $20 \mathrm{kWh}$ ( $64 \%$ of total solar yield) of energy whereas for DHW, the energy usage is only $5.85 \mathrm{kWh}$ ( $18.5 \%$ of total solar yield).

From experiments, assuming the same solar yield, it has been found that MD utilizes $12.92 \mathrm{kWh}(41 \%$ of total solar yield) of energy whereas the energy utilization for DHW is $5.63 \mathrm{kWh}$ (18\% of total solar yield). Assuming the same solar yield for the experiments, only $41 \%$ of total yield has been utilized by MD and $18 \%$ for DHW production. The total volume of distillate collected was $16 \mathrm{~L}$ with energy consumption of $0.804 \mathrm{kWh} / \mathrm{L}$. Practically, the losses could be avoided by proper insulation around the copper piping and by installing the thermal storage tank near to the collectors.

If we assume the simulation results as real case scenario, then it is obvious that extra available energy used for MD is $7.3 \mathrm{kWh}$ (23.3\% of total solar yield). By utilizing this energy, more pure water can be produced. It has been estimated that $36 \%$ more water production can be obtained with same operational hours of MD. The experimental and simulation plots for MD hourly energy consumption along with collector outlet temperature, tank top temperature and MD hot inlet temperature are shown in Fig. 12. It can be observed that there is a difference of $5^{\circ} \mathrm{C}$ between the simulated and experimental values of collector outlet temperatures and MD energy consumption trend is also greater in simulated data.

During the early hours of plant operation, the MD hot inlet and tank top temperature also shows the slight drop. The reason for the drop could be explained due to the fact that the DHW has been withdrawn in the morning hours instead of following the proper withdrawal profile as shown in Fig. 13. This sudden drop in the tank top temperature is due to the uncontrolled draw off of the DHW. The vertical green bars show the hourly simulated values for DHW energy profile whereas the pink vertical bars are the experimental values. The average domestic hot water that has been withdrawn from experiments was $273 \mathrm{~L}$ at an average temperature of about $50^{\circ} \mathrm{C}$.

Aperture area $-7.08 \mathrm{~m}^{2}$ : The three flat plate collectors have been aligned now into a single array constituting a total aperture area of $7.08 \mathrm{~m}^{2}$ which is the lower aperture area. To maintain a balance between the outlet temperature and harvested thermal energy, the specific flow rate has been

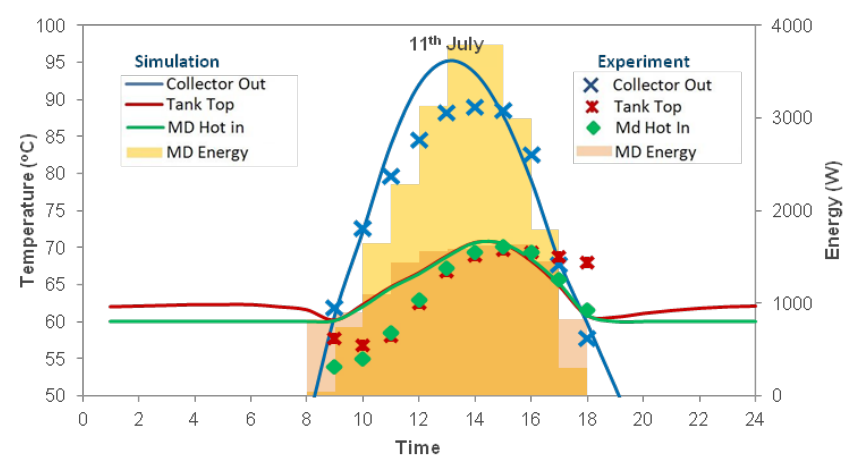

Fig. 12. MD temperature and energy profile [24].

Table 2

Simulation and experimental data: flat plate collector (FPC) aperture area $11.85 \mathrm{~m}^{2}$ [24]

\begin{tabular}{|c|c|c|}
\hline Parameter & Value & Remarks \\
\hline Specific flow rate, $1 / \mathrm{h} / \mathrm{m}^{2}$ & 11.2 & Low for achieving high outlet temperature \\
\hline \multicolumn{3}{|l|}{ Simulation data } \\
\hline Total solar yield, kWh & 31.3 & $12 \mathrm{~h}$ \\
\hline MD energy use, kWh & 20 & $64 \%$ of total solar yield \\
\hline DHW energy use, $\mathrm{kWh}$ & 5.85 & $18.5 \mathrm{kWh}$ \\
\hline Losses, $\%$ & 17.5 & Long length piping - more losses \\
\hline \multicolumn{3}{|l|}{ Experimental data } \\
\hline Distillate collected, L & 16 & $10 \mathrm{~h}$ plant operation \\
\hline MD energy use, kWh & 12.92 & $0.804 \mathrm{kWh} / \mathrm{L}$ \\
\hline DHW energy use, kWh & 5.63 & Not withdrawn according to domestic hot water profile \\
\hline \multicolumn{3}{|l|}{ Estimated values } \\
\hline Extra available energy, kWh & 7.3 & Total $_{\text {Sim }}-$ Total $_{\text {Exp }}$ \\
\hline Estimated distillate volume, $\mathrm{L}$ & 25 & $36 \%$ more water production \\
\hline
\end{tabular}


adjusted slightly higher from previous experiments. From Table 3, the values clearly show that the solar yield reduced due to less collector area. The simulated results for $10 \mathrm{~h}$ plant operation show the total solar yield of $21.2 \mathrm{kWh}$. Out of this, MD uses $11.3 \mathrm{kWh}$ of energy (53.5\% of total solar yield) whereas DHW uses $5.85 \mathrm{kWh}$ (27.5\% of total solar yield) of energy to produce the fixed volume of hot water. Similarly, from experimental analysis for $9.25 \mathrm{~h}$ of plant operation, MD energy consumption is $8.3 \mathrm{kWh}$ (39\% of total solar yield) whereas DHW consumes $5.2 \mathrm{kWh}$ ( $24.5 \%$ of total solar yield) of energy. The total volume of distillate collected was $8.5 \mathrm{~L}$ with energy consumption of $0.975 \mathrm{kWh} / \mathrm{L}$ at MD hot inlet temperatures ranging from $50^{\circ} \mathrm{C}$ to $55^{\circ} \mathrm{C}$.

As compared with the previous experiments, the temperature profiles obtained for the simulation and experiment results show large variation as shown in Fig. 14. There is a temperature difference of around $10^{\circ} \mathrm{C}$ between MD hot inlet and tank top. The low tank temperature is merely due to

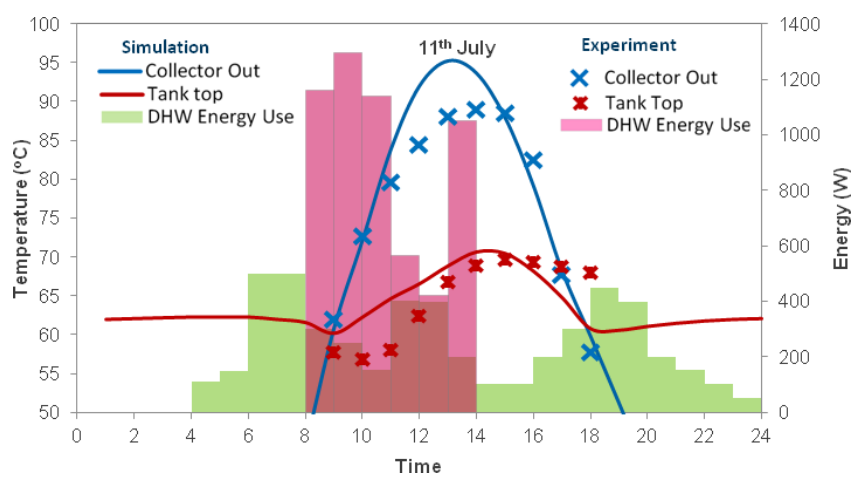

Fig. 13. Domestic hot water (DHW) temperature and energy profile [24].

Table 3

Simulation and experimental data for flat plate collector of aperture area $7.08 \mathrm{~m}^{2}[24]$

\begin{tabular}{|c|c|c|}
\hline Parameter & Value & Remarks \\
\hline Specific flow rate, $1 / \mathrm{h} / \mathrm{m}^{2}$ & 17 & $\begin{array}{l}\text { Medium flow } \\
\text { conditions }\end{array}$ \\
\hline \multicolumn{3}{|l|}{ Simulation data } \\
\hline Solar yield, kWh & 21.2 & $12 \mathrm{~h}$ \\
\hline MD energy use, $\mathrm{kWh}$ & 11.3 & $\begin{array}{l}53.5 \% \text { of total solar } \\
\text { yield }\end{array}$ \\
\hline DHW energy use, $\mathrm{kWh}$ & 5.85 & $\begin{array}{l}27.5 \% \text { of total solar } \\
\text { yield }\end{array}$ \\
\hline Losses, $\%$ & 19 & Long length piping \\
\hline \multicolumn{3}{|l|}{ Experimental data } \\
\hline Distillate collected, L & 8.5 & $9.25 \mathrm{~h}$ of operation \\
\hline MD energy use, kWh & 8.3 & $0.975 \mathrm{kWh} / \mathrm{L}$ \\
\hline DHW energy use, kWh & 5.2 & 3 peaks withdrawal \\
\hline \multicolumn{3}{|l|}{ Estimated values } \\
\hline Extra available energy, kWh & 3.7 & Total $_{\text {Sim }}-$ Total $_{\text {Exp }}$ \\
\hline Estimated $V_{\mathrm{Dis},} \mathrm{L}$ & 12.5 & $\begin{array}{l}32 \% \text { more } \\
\text { production }\end{array}$ \\
\hline
\end{tabular}

increase in flow rate and pipe losses collectively. Therefore, it is reasonable to estimate excess energy taking simulation as actual case and hence $32 \%$ more distillate production could be obtained. However, the actual demand of $20 \mathrm{~L} / \mathrm{d}$ has not been fulfilled by this collector array configuration which further suggests the fact that MD system must need to be operated for more hours.

Instead of random withdrawal of DHW as in previous case, DHW has been withdrawn following three peaks of demand profile. The experimental data for tank top shows the dips in the morning plant operation and rapid discharge of the storage tank. This is because of the simultaneous operation of MD and DHW circuits.

Around the noon time, the temperature starts to stabilize approaching to a trend similar to the simulation data. So from the results obtained, it is obvious that the aperture area of $7.08 \mathrm{~m}^{2}$ for the flat plate collector is insufficient to fulfill the benchmark demand for MD and DHW.

\subsubsection{Evacuated tube collectors}

The RAKRIC facility has an evacuated tubular collector field array consisting of 3 collectors, 16 tubes with aperture area of $9.024 \mathrm{~m}^{2}$. In order to maximize the thermal energy yield, the specific flow rate has been set high (manufacturer's recommendation). The experimentation results are summarized in Table 4. It is obvious from the simulation results that the obtained solar yield from evacuated tube collectors is higher than the yield obtained with flat plate collectors having more aperture area (section 7.3.1) which confirms the fact that higher flow rates lead to high thermal yield. From total solar yield of $36.4 \mathrm{kWh}$, MD system consumed $26 \mathrm{kWh}$ (71.5\% of total yield) and DHW system consumed $5.85 \mathrm{kWh}$ (16\% of total yield) whereas the $12.5 \%$ of energy has been lost due to long length of piping installation. The heat losses have been minimized due to turbulent flow conditions. Moreover, from the experimental results, it was observed that $44 \%$ of the total yield has been utilized for MD (16 kWh) and 14.3\% (5.2 kWh) for DHW. Since the estimated production of distillate is $28 \mathrm{~L}$ which means that $40 \%$ more production can be possible with this setup of evacuated tube collectors (ETC) of aperture area of $9.024 \mathrm{~m}^{2}$.

According to the data available from the experimentation results from 22nd July, the MD energy and temperature profile have been drawn and is shown in Fig. 16. Moreover the DHW temperature and energy profile has been shown in Fig. 15.

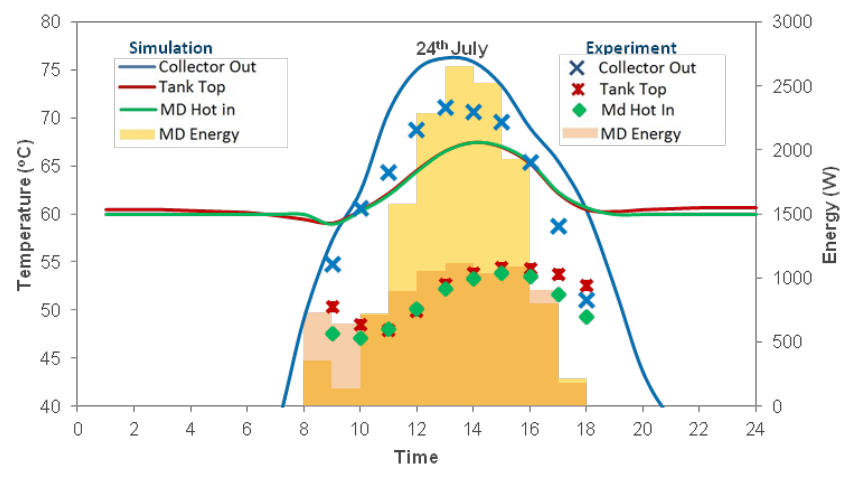

Fig. 14. MD temperature and energy profile [24]. 
Table 4

Simulation and experimental data comparison for ETC aperture area $9.024 \mathrm{~m}^{2}[24]$

\begin{tabular}{|c|c|c|}
\hline Parameter & Value & Remarks \\
\hline Specific flow rate, $1 / \mathrm{h} / \mathrm{m}^{2}$ & 28 & $\begin{array}{l}\text { High to maximum } \\
\text { energy }\end{array}$ \\
\hline \multicolumn{3}{|l|}{ Simulation data } \\
\hline Solar yield, kWh & 36.4 & $12 \mathrm{~h}$ \\
\hline MD energy use, $\mathrm{kWh}$ & 26 & $71.5 \%$ of total yield \\
\hline DHW energy use, kWh & 5.85 & $16 \%$ of total yield \\
\hline Losses, \% & 12.5 & Long length piping \\
\hline \multicolumn{3}{|l|}{ Experimental data } \\
\hline Distillate collected, L & 17 & $9.67 \mathrm{~h}$ of operation \\
\hline MD energy use, $\mathrm{kWh}$ & 16 & $0.94 \mathrm{kWh} / \mathrm{L}$ \\
\hline DHW energy use, kWh & 5.2 & 3 peaks withdrawal \\
\hline \multicolumn{3}{|l|}{ Estimated values } \\
\hline Extra available energy, $\mathrm{kWh}$ & 10.6 & Total $_{\text {Sim }}-$ Total $_{\text {Exp }}$ \\
\hline Estimated $V_{\text {Dis' }}, \mathrm{L}$ & 28 & $\begin{array}{l}40 \% \text { more } \\
\text { production }\end{array}$ \\
\hline
\end{tabular}

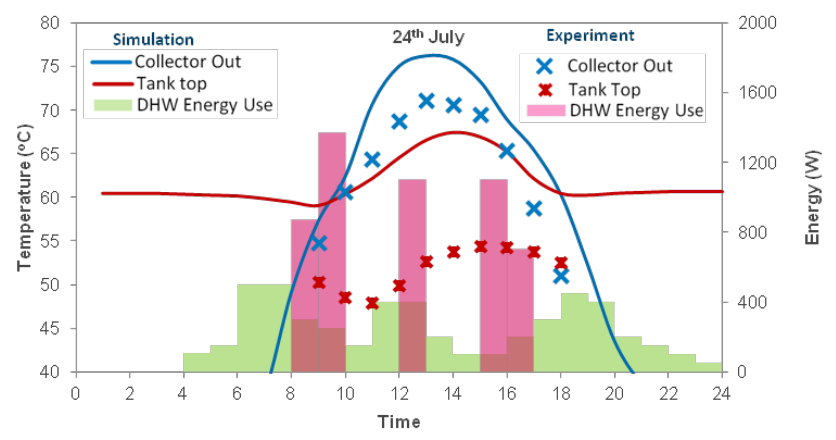

Fig. 15. DHW temperature and energy profile [24].

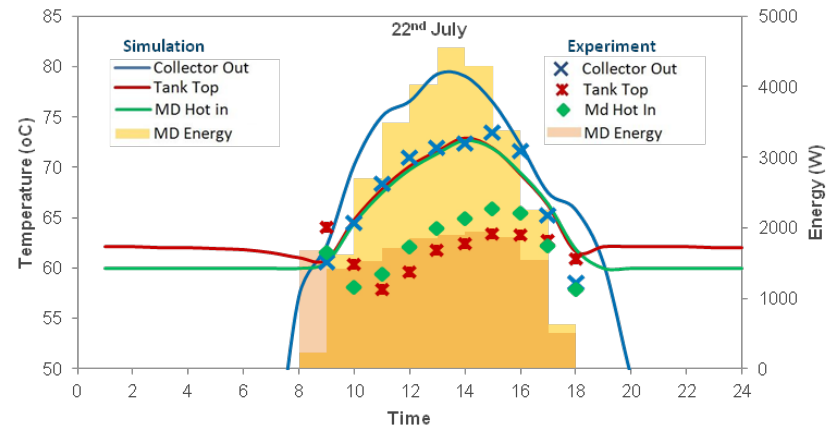

Fig. 16. MD temperature and energy profile [24].

The temperature profiles of MD hot inlet and storage tank top layer shows the interesting results during experimentation. The trend explains that the top layer of the storage tank charges more rapidly due to high specific flow rates and the layer from which the MD hot inlet water is taken gets much more heated than top layers of the storage tank. This gives us

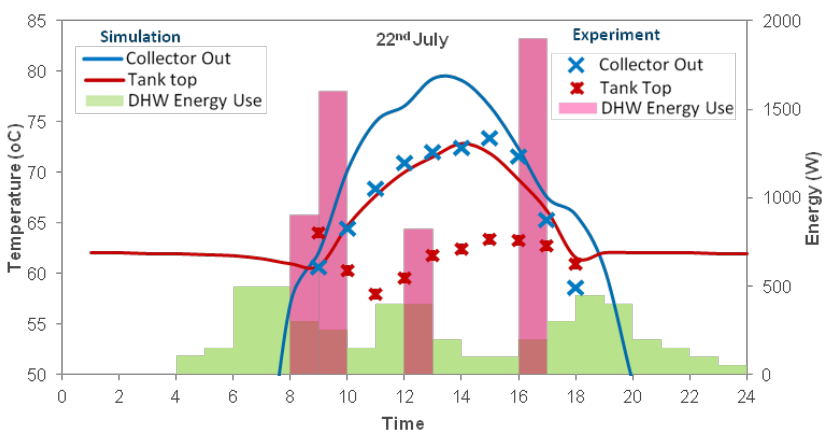

Fig. 17. Domestic hot water temperature and energy profile [24].

an advantage of getting hot water at higher temperature for MD. The domestic hot water energy profile and temperature profile is shown in Fig. 17. Due to dual demand (hot water and drinking water), low radiation and unstable operation in the morning hours, there is a sudden temperature drop in the tank top layer during. During the complete plant run, the domestic hot water has been drawn in three peaks:

- First peak between 8 AM and 10 AM

- Second peak between 12 PM and 1 PM

- Third peak between 4 PM and 5 PM

From Table 4, it is obvious that we can obtain the excess energy as per simulation data which contributes to about $40 \%$ more distillate production. The simulated results show that we can produce $28 \mathrm{~L}$ of pure water for $10 \mathrm{~h}$ of plant operation compared with $16 \mathrm{~L}$ of pure water during real time experimentation. In real time situations, the key is to minimize the losses and operating the plant at reasonably high flow rates. So, the aperture area of $9.024 \mathrm{~m}^{2}$ is ideal to fulfill the overall demand of MD and DHW as well.

\section{Determination of optimum collector area}

\subsection{Annual water production and energy demand profiles}

The lab scale experimentation research has been performed in RAKRIC facility on solar thermal integrated MD system. Based on the results, the thermal energy consumption patterns for variable ranges of MD inlet hot and cold temperatures have been determined. Table 5 provides the thermal energy consumption per liter of pure water for different MD hot inlet and cold inlet temperature ranges for different periods (values indicated in italics) using the equation:

$Q=m^{\circ} C_{p}\left(T_{\text {hin }}-T_{\text {hout }}\right)$

The consumption of pure water varies yearly, that is, pure water consumption is more in summers than in winters. So $15 \mathrm{~L} / \mathrm{d}$ of pure water consumption is estimated in winter days, that is, from December to February, $20 \mathrm{~L} / \mathrm{d}$ is estimated from March to June and in October and November and $25 \mathrm{~L} / \mathrm{d}$ of pure water consumption is estimated in peak summer days, that is, from July to September. Therefore, the total estimated yearly volume of pure water or distillate is $7,300 \mathrm{~L}$. Assuming that the temperature ranges mentioned in Table 5 would be available for MD in the periods mentioned 
above; the annual energy demand for pure water production will be around 6,000 kWh as shown in Fig. 18. The plot has also been drawn in Fig. 19.

Similarly, according to ESTIDAMA standards, the annual energy demand for domestic hot water has also been calculated. With the fixed volume of $250 \mathrm{~L} / \mathrm{d}$ at $50^{\circ} \mathrm{C}-55^{\circ} \mathrm{C}$, the cold water temperature of $14^{\circ} \mathrm{C}$ in winters and $30^{\circ} \mathrm{C}$ in summers, the annual demand for domestic hot water is 2,968 $\mathrm{kWh}$. By recirculating and recovering the heat from MD cold side

Table 5

Temperature and energy estimations for yearly pure water profile [24]

\begin{tabular}{|c|c|c|c|}
\hline \multirow{2}{*}{$\begin{array}{l}\text { Parameter } \\
\text { MD hot in temperature, }{ }^{\circ} \mathrm{C}\end{array}$} & \multicolumn{3}{|c|}{$\begin{array}{l}\text { Operational range/energy/ } \\
\text { months }\end{array}$} \\
\hline & $50-55$ & $55-60$ & $60-65$ \\
\hline MD cold in temperature, ${ }^{\circ} \mathrm{C}$ & $14-16$ & $18-25$ & $28-30$ \\
\hline $\begin{array}{l}\text { Energy consumed for pure } \\
\text { water, } \mathrm{kWh} / \mathrm{L} \text { production }\end{array}$ & 1 & 0.85 & 0.7 \\
\hline $\begin{array}{l}\text { Period during which } \\
\text { temperatures are available }\end{array}$ & $\begin{array}{l}\text { Dec, } \\
\text { Jan, Feb }\end{array}$ & $\begin{array}{l}\text { Mar-Jun, } \\
\text { Oct, Nov }\end{array}$ & $\begin{array}{l}\text { Jul, Aug, } \\
\text { Sep }\end{array}$ \\
\hline
\end{tabular}

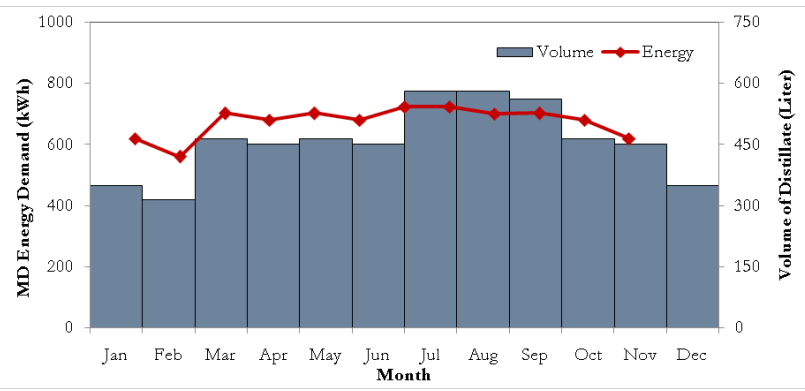

Fig. 18. Annual pure water production profile and MD energy demand [24].

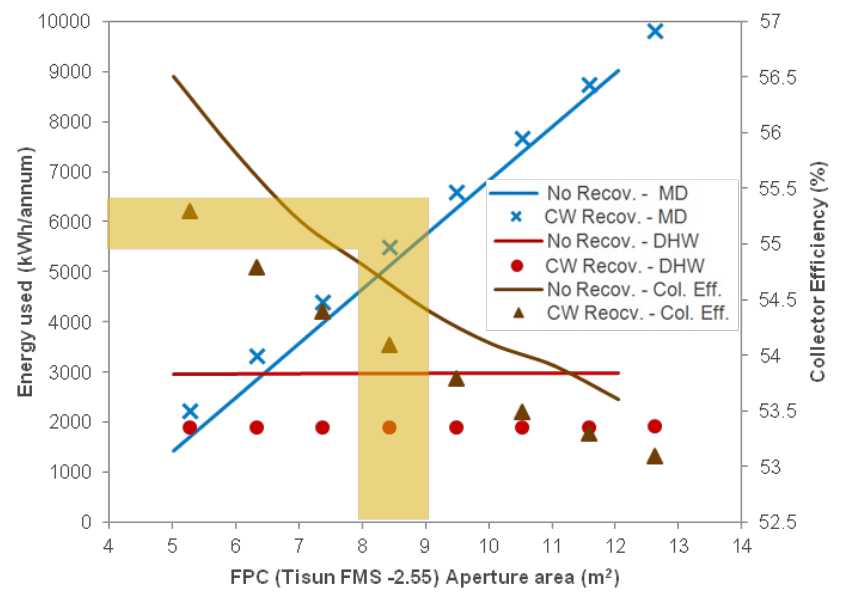

Fig. 19. Optimum flat plate collector area for solar thermal integrated MD system [24]. return, we can preheat the water for DHW circuit and thus the total annual energy demand will be reduced to 2,223 $\mathrm{kWh}$. It means that from waste heat recovery from MD cold side return, we can save about $25 \%$ of energy for domestic hot water production resulting in reduced energy demand. Table 6 provides annual energy demand values for MD and DHW.

\subsection{Optimum collector area determination}

For determining the collector area to fulfill the energy demand of solar thermal integrated system, PolySun simulation software has been used. The calculations are based on $10 \mathrm{~h}$ of daily plant operation assuming $100 \%$ annual solar fraction. It means that the MD system would be operated in sunlight hours and the domestic hot water requirement would be fulfilled through the thermal storage system. Following models of flat plat collectors and evacuated tube collectors have been used for experimentation:

- Flat plate collector - Tison FMS-2.55

- Evacuated tube collector - Sunda SolarSiedo 1-16

Fig. 19 shows the graphs of the flat plate collector efficiency and aperture area against the annual energy demand. The trends have been drawn for both MD cold side waste heat recovery and without MD cold side waste heat recovery. A careful consideration shows that the flat plate aperture area of $8-9 \mathrm{~m}^{2}$ is sufficient to achieve the benchmark production and overall energy demand for both MD and DHW. The highlighted area shows the optimum flat plate collector area to fulfill the desired energy demand for MD and DHW.

In a similar way, Fig. 20 shows the graph for the evacuated tube collector aperture area against collector efficiency. It can be seen that the collector area of $7-8 \mathrm{~m}^{2}$ is sufficient to meet overall energy demand for MD and DHW.

In MENA region, the collector field of normally $5 \mathrm{~m}^{2}$ is used for the production of hot water to meet the hot water demand for domestic purposes. So, by this study, the addition of minimum $3 \mathrm{~m}^{2}$ aperture area will be sufficient to meet the pure water demand for a single family villa. Table 7 summarizes the average area required for SDHW-MD system for a system installed on top of a villa in UAE region.

\section{Conclusions}

The whole experimental analysis and study performed on the solar thermal integrated system installed in RAKRIC has been concluded and following results have been drawn based on the experiments performed for benchmark production and optimum collector area:

Table 6

Annual energy demand for MD and DHW [24]

\begin{tabular}{ll}
\hline Parameter & Value \\
\hline MD annual energy demand, kWh & 6,000 \\
DHW annual energy demand, kWh & 2,968 \\
DHW demand with MD heat recovery, kWh & 2,223 \\
\hline
\end{tabular}




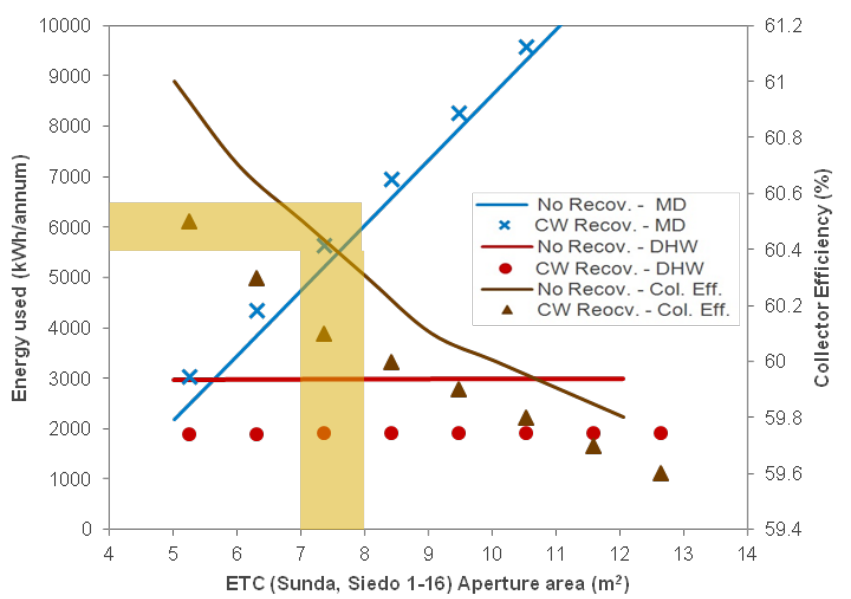

Fig. 20. Optimum evacuated tube collector area for solar thermal integrated MD system [24].

Table 7

Summary of optimum collector area required [24]

\begin{tabular}{lll}
\hline Collector type & FPC & ETC \\
\hline Aperture area, $\mathrm{m}^{2}$ & 8.5 & 7.5 \\
Solar yield, kWh/year & 9,800 & 9,700 \\
$\begin{array}{l}\text { Energy use for MD, } \\
\text { kWh/year }\end{array}$ & $5,900(60 \%)$ & $5,700(58.5 \%)$ \\
$\begin{array}{l}\text { Energy use for DHW, } \\
\text { kWh/year }\end{array}$ & $2,100(21.5 \%)$ & $2,100(22 \%)$ \\
Total losses, kWh/year & $1,800(18.5 \%)$ & $1,900(19.5 \%)$ \\
\hline
\end{tabular}

- The integration of MD with solar domestic hot water system is feasible for the cogeneration and sustainable production of 15-25 L/d per person of pure drinking water along with domestic hot water. Based on pure water usage pattern, the production of distillate will be less in winter, that is, from December to January and more in peak summer, that is, from July to September.

- For the simultaneous production of 15-25 L/d of pure drinking water, $250 \mathrm{~L} / \mathrm{d}$ of domestic hot water and to meet the annual energy demand, the optimum flat plate and evacuated tube collector area is found to be 8.5 and $7.5 \mathrm{~m}^{2}$, respectively, for producing the required pure water and domestic hot water for single family.

- From AGMD unit used in the MD system for distillate production, the optimum hot water side and cold water side flow rates are 6 and $3 \mathrm{~L} / \mathrm{min}$. The hot side temperature and cold side temperature should be maintained between $60^{\circ} \mathrm{C}$ and $70^{\circ} \mathrm{C}$, and $20^{\circ} \mathrm{C}$ and $30^{\circ} \mathrm{C}$, respectively.

- The integrated system leads to efficient utilization of the standard domestic hot water system in summer time by reducing the backup heating and pure water production. Moreover, the domestic hot water energy demand can be reduced to about $25 \%$ by recovering the energy from MD cold side which maximizes the energy input to MD, thereby, increasing the distillate production.

- For solar thermal integrated MD system for production of hot water and drinking water, the total annual energy demand is $8,223 \mathrm{kWh}$ of which $6,000 \mathrm{kWh}$ is for pure water and 2,223 $\mathrm{kWh}$ is for hot water. So, by recovering the hot water from MD cold side, the energy demand for pure water will only be $73 \%$.

\section{Acknowledgments}

The authors would like to extend their gratitude to the Ras Al Khaimah Investment Authority (RAKRIC) for their financial support. Special thanks to KTH Royal Institute of Technology, Stockholm, for their fruitful cooperation in the project.

\section{References}

[1] M.F. Al-Rashed, M.M. Sherif, Water resources in the GCC countries: an overview, Water Resour. Manage., 14 (2000) 59-75.

[2] A.A. Murad, H. Al Nuaimi, M. Al Hammadi, Comprehensive assessment of water resources in the United Arab Emirates (UAE), Water Resour. Manage., 21 (2007) 1449-1463.

[3] http://www.domdudley.com/articles/2015/09/21/uaes-bottledwaters-brands-battle-for-market-share (Accessed 10 March 2016).

[4] S.M. Al-Ghais, Water Resources in the UAE, General Trends and Our Impact on the Environment, Frontiers in Water, Energy and Sustainability, 2013, pp. 44-48.

[5] S. Szabo, The water challenge in the UAE, 2011.

[6] http://idadesal.org/desalination-101/desalination-by-thenumbers (Accessed 10 March 2016).

[7] http://www.emirates247.com/business/uae-is-world-s-secondlargest-desalination-producer-2012-12-24-1.488486 (Accessed 10 March 2016).

[8] M.K. Souhaimi, T. Matsuura, Membrane Distillation: Principles and Applications, Elsevier, 2011.

[9] E. Drioli, A. Criscuoli, E. Curcio, Membrane Contactors: Fundamentals, Applications and Potentialities, Elsevier, 2011.

[10] E.K. Summers, H.A. Arafat, J.H. Lienhard, Energy efficiency comparison of single-stage membrane distillation (MD) desalination cycles in different configurations, Desalination, 290 (2012) 54-66

[11] S. Cerneaux, I. Strużyńska, W.M. Kujawski, M. Persin, A. Larbot, Comparison of various membrane distillation methods for desalination using hydrophobic ceramic membranes, J. Membr. Sci., 337 (2009) 55-60.

[12] Z. Ding, L. Liu, Z. Li, R. Ma, Z. Yang, Experimental study of ammonia removal from water by membrane distillation (MD): the comparison of three configurations, J. Membr. Sci., 286 (2006) 93-103.

[13] G.W. Meindersma, C.M. Guijt, A.B. De Haan, Desalination and water recycling by air gap membrane distillation, Desalination, 187 (2006) 291-301.

[14] A. Chafidz, E.D. Kerme, I. Wazeer, Y. Khalid, A. Ajbar, M Al-Zahrani, Design and fabrication of a portable and hybrid solar-powered membrane distillation system, J. Cleaner Prod., 133 (2016) 631-647.

[15] A. Kullab, C. Liu, A.R. Martin, Solar Desalination Using Membrane Distillation: Technical Evaluation Case Study, Solar World Congress 2005: Bringing Water to the World, Including 34th ASES Annual Conference and 30th National Passive Solar Conference; Orlando, FL, United States, 6-12 August, 2005, pp. 2732-2737.

[16] F.A. Banat, J. Simandl, Theoretical and experimental study in membrane distillation, Desalination, 95 (1994) 39-52.

[17] A. Kullab, Desalination Using Membrane Distillation: Experimental and Numerical Study, PhD dissertation, KTH Royal Institute of Technology, 2011.

[18] M.R. Qtaishat, F. Banat, Desalination by solar powered membrane distillation systems, Desalination, 308 (2013) 186-197.

[19] A. Alkhudhiri, N. Darwish, N. Hilal, Produced water treatment: application of air gap membrane distillation, Desalination, 309 (2013) 46-51. 
[20] P. Wang, T.-S. Chung, Recent advances in membrane distillation processes: membrane development, configuration design and application exploring, J. Membr. Sci., 474 (2015) 39-56.

[21] H.C. Duong, P. Cooper, B. Nelemans, T.Y. Cath, L.D. Nghiem, Evaluating energy consumption of air gap membrane distillation for seawater desalination at pilot scale level, Sep. Purif. Technol., 166 (2016) 55-62.

[22] D.U. Lawal, A.E. Khalifa, Experimental investigation of an air gap membrane distillation unit with double-sided cooling channel, Desal. Wat. Treat., 57 (2016) 11066-11080.

[23] https://www.slideshare.net/dahirulawal509/flux-optimizationin-air-gap-membrane-distillation-system-for-waterdesalination-52061469.

[24] M. Asim, Experimental Analysis of Integrated System of Membrane Distillation for Pure Water with Solar Domestic Hot Water, KTH Library, 2013.

[25] M. Abu-Zeid, A. El-Rady, Y. Zhang, H. Dong, L. Zhang, H.-L. Chen, L. Hou, A comprehensive review of vacuum membrane distillation technique, Desalination, 356 (2015) 1-14.
[26] http://estidama.org/estidama-villa-products-database/ solar-hot-water-systems.aspx (Accessed 15 February 2015).

[27] https://estidama.upc.gov.ae/estidama-and-pearl-rating-system. aspx?lang=en-US.

[28] U. Kumar, H. Kayal, R.A. Martin, Sustainable Co-production of Drinking Water and Domestic Hot Water Using Membrane Distillation Integrated Solar Thermal System, UAE Swiss Research Forum, Abu Dhabi, Dubai, 2012.

[29] N.T.U. Kumar, A. Martin, Co-generation of drinking water and domestic hot water using solar thermal integrated membrane distillation system, Energy Procedia, 61 (2014) 2666-2669.

[30] N.T.U. Kumar, A.R. Martin, Co-production performance evaluation of a novel solar combi system for simultaneous pure water and hot water supply in urban households of UAE, Energies, 10 (2017) 481. 